\title{
Investigating Teachers' Work with Digital Resources. A Comparison Between the Teaching of Mathematics and English
}

\section{Brigitte Gruson, Ghislaine Gueudet, Carole Le Hénaff and Marie-Pierre Lebaud}

The abundant digital resources on the Internet are leading to profound changes in teachers' activity. We refer to the theoretical framework and methodology of the documentational approach to didactics to investigate these changes. We compare two case studies: an English teacher, and a mathematics teacher, both working in the same upper secondary school in France. We have observed significant use of digital resources in both cases, but of a different nature. We present and discuss these differences that shed light upon teachers' documentational work. We use these cases to draw more general conclusions on designing, using and sharing digital teaching resources.

At all school levels and in all subjects, teachers work with a variety of resources: paper textbooks, software, lesson plans and so on. Recently available resources have dramatically increased: in many countries, teachers have access via the Internet to an abundance of open source material, free of charge. The national research project REVEA in France studies the consequences of these developments for teachers working in secondary education and teaching different school subjects: Biology, English, Mathematics, Physics and Technology. The work we present here comes from this project and builds on a particular didactical perspective.

We maintain that analyzing the development of teachers' work within this context requires a specific theoretical approach. We have developed for this purpose the documentational approach to didactics (Gueudet, Pepin \& Trouche, 2012), a theoretical approach (section 1) drawing on the instrumentation theory (Rabardel, 1995) and introducing the concepts of teachers' documentation work, resources and documents in particular. This theory is associated with a specific methodology called «reflexive investigation». In this paper, we develop this methodology further (section 2) notably by considering teachers teaching different subjects and by comparing their documentation work. We illustrate this method by using it to study two upper-secondary school teachers in France, one teaching English and the other mathematics (section 3). We discuss the 
results obtained through this comparison (section 4) and conclude about the possible contribution of this method to the field of educational research (section 5).

\section{Teachers' work with resources: a theoretical approach}

The general perspective guiding the development of the documentational approach comes from the activity theory (Vygotsky, 1978). We consider that a subject, in our case a teacher, is engaged in a goal-directed activity. To achieve this goal, the teacher interacts with a variety of artefacts. These artefacts can be modified by him/her: according to his/her precise goal, the teacher can delete parts of the artefact, complete it, combine several together and so on. At the same time, the artefact influences the teacher's choices and can even lead to changes in the object of the activity. Rabardel (1995) introduced the instrumentation theory, considering that alongside his/her use of an artefact in a goal-directed activity, a subject develops a mixed entity: an instrument, composed of the artefact and schemes of use of this artefact (Vergnaud, 1998). A scheme is a stable organization of the activity. It has several components: the aim of the activity (with possible sub-aims), rules of action and operational invariants that can be concepts-inaction or theorems-in-action. A concept-in-action is a concept considered (by the subject) as relevant, a theorem-in-action is a statement considered as true.

The instrumentation theory has been used in a wide range of research on the use of software at school by students (see e.g. Guin, Ruthven \& Trouche 2005). The development of teachers' working contexts, quickly referred to above, has led us to develop a specific theoretical approach, the documentational approach of didactics (Gueudet et al., 2012) that draws on the instrumentation theory and extends it. Instead of focusing on 'artefacts', we consider a more general notion of 'resource', following Adler (2000, p. 207) who suggests that «it is possible to think about a resource as the verb re-source, to source again or differently». A teacher engaged in a goal-directed activity interacts with resources of various kinds: textbooks, students' productions, software, e-mails exchanged with colleagues etc. He/she transforms these resources, sets them up in class with students. To name this process outcome we introduced the term "document», coming from documentation engineering (Pédauque, 2006). In this field, a document is associated with a precise use. Within the documentational approach, we consider that together with his/her use of resources, the teacher develops a document, combining resources and a scheme of didactic use of these resources, incorporating in particular operational invariants (Vergnaud, 1998). This process, i.e. developing a document alongside the work with resources, is called a documentational genesis.

The notion of operational invariant is central, in Vergnaud's theory, for modelling the conceptualization taking place along the subject's activity. For 
teachers working with resources, some of the operational invariants come from socio-historical aspects of their professional activity and hence can be shared by all teachers of the same discipline, while others are more individual. The interactions with resources can contribute to the development of both kinds of operational invariants. Indeed, some of the resources, like textbooks, are the outcome of a didactical transposition process (Chevallard \& Joshua, 1991) and incorporate institutional features of the discipline, while others, like students' productions, are more individual.

The documentational approach has been used in several pieces of research considering teachers at various levels, from primary to higher education. This research has demonstrated that a teacher develops many documents alongside his/her work, organized according to his/her activity. The structured set of these documents composes the teacher's documentation system. The documentation system comprises resources - which constitute the teacher's resource system and schemes of use of these resources. Analyzing the documentation system of a teacher allows us in particular to understand the interactions between the teacher's operational invariants and his/her documentation work.

Using the theory presented above, we can formulate our research questions as follows:

- What are the documents developed by teachers, in particular, how do teachers' operational invariants interact with their documentation?

- What is the impact of digital resources and of their availability on teachers' documentation work?

We do not intend to present a complete answer to these questions, but to investigate them for specific teaching contents, drawing on case studies.

\section{Analyzing teachers' documentation work and its outcomes: methods}

In this paper we adopt a case study method, i.e. an intrinsic analysis of a phenomenon, the teachers' documentation work. Following Passeron and Revel (2005), we claim that «the case demonstrates [and that] the strength of the evidence grows with the occurrence of other cases, analogue or related». From this perspective, we adopt a case study approach «(in) which the simultaneous increase in generality and accuracy [of the results] would not be reduced to that of inductive generalization, or of deductive necessity» (Passeron \& Revel, 2005, p. 37). The objective is thus not to over-generalize from particular phenomena but to better understand the complexity of the phenomena we study. A questionnaire (Boilevin et al., 2016, May) about the use of resources completed by teachers of different academic subjects showed that documentation work can be very variable according to the subject. We have chosen two subjects where important 
differences appear, English and Mathematics, and describe here a comparative study of two teachers, one for each subject. The analysis of these two teachers enables us to study more general issues related to teachers' documentation work.

In this section we present three important aspects of our method: data collection; data analysis, using 'documentation tables' and interdisciplinary comparison.

\section{Collection of data: the reflective investigation.}

Our starting point is the methodology associated with the documentational approach, which we call the 'reflective investigation' of a teacher's documentation system. This methodology follows several principles:

- The teacher's work is observed by the researcher in and out of class;

- A long-term follow-up is organized, for one or several school years;

- The teacher reflects on his/her own work: he/she provides comments on videos of his/her activity filmed by the researcher, which enables the researcher to confirm that we use a «shared practice language» (Collins, 2011);

- The data provided by the teacher are compared with actual observations by the researcher.

In the cases presented and analyzed here, we followed two teachers working in the same upper secondary school (grades 10 to 12):

- Coralie teaches English. She has 20 years of experience as a secondary teacher but only 3 years in upper secondary education;

- Valeria teaches mathematics. She has 33 years of experience as a secondary teacher (with only 4 years in lower secondary education).

For each teacher, we collected the following data:

- General data: a questionnaire about the teacher's profile; a general interview on the teacher's resources; representation of the teacher's resource system.

- Data concerning a specific teaching unit: a video of the preparation of a lesson; a video of the lesson, interviews after the lesson; a logbook completed by the teacher throughout the process; collection of their main resources.

So that for each case, we have a large amount of diverse data, which requires us to make methodological choices depending on our research questions. For example, we need to compare/contrast the teachers' statements with data that does not depend on the teacher's interpretation in order to identify the aims of the activity, that the teacher may or may not be aware of. For this reason we have developed a particular way to handle the data.

\section{Analyzing the data: building documentation tables}

In this paper, we focus on the teacher's activity in relation to a given theme (we do not take into account the organization of the whole year, individual follow-ups of students, etc.). 
We start from the transcript of the interviews and try to identify the different goals of the teachers' activity. Some of these goals are identified by the teachers themselves; others are identified by the researcher from observations of the teacher's work in class. Then, for each goal, we identify the resources used (drawing on the interviews, the videos and the resources collected), together with elements of the schemes associated with these resources.

We fill in a "documentation table», with the following elements: the different goals of the teacher's activity; the resources used for each of these goals; how these resources are used (rules of action); and the operational invariants underlying their use (in what follows, we use the abbreviation o.i. to denote operational invariants). To identify o.i., we observe in the interviews declarations corresponding to statements considered as true, and we confront them with the teacher's actual activity. Each line of the table corresponds to a document; and the whole table can be considered as a representation of a documentation system. The output is a draft documentation table, which is then submitted to the teacher for corrections and additions. In order to examine the 'patterns of intention' (Baxandall, 1985) underlying the teachers' documentation work, we do not try to study a "reconstituted historical state of mind, (...) but a relation between the object and its circumstances» (Baxandall, 1985, p. 42). Sensevy (2011) adds that such intentions do not only apply to persons, but also to resources. Examples of documentation tables are given in the next section.

\section{Interdisciplinary comparison: what can we Learn?}

Research work using the documentational approach has mostly studied Mathematics teachers in secondary education. Naturally all teachers interact with resources, and our questionnaire has demonstrated important differences in the resources used by teachers for different subjects. Using a comparative approach (Mercier, Schubauer-Leoni \& Sensevy, 2002) allows us to make some specific features of the documentational process more visible, and thus to characterize some general elements of teachers' documentation work. We follow, among others, Sensevy, Gruson and Forest (2015), who suggest:

Under the generic descriptions that these concepts provide, the teacher's action may be viewed as dealing with the same kind of necessities, whatever the institutional settings in which it unfolds. [...] The comparative stance allows us to precisely institute our concepts in different concretes, and, in doing so, to continuously reshape these concepts, and to continuously augment their relevance. (p. 410)

Following Ligozat, Amade-Escot and Östman (2015) we consider that:

Comparative analyses have the potential to bring together different facets of classroom reality ranging from micro-scale situated events to institutional norms and determinants pre-constructed in teaching traditions and curriculum texts. Beyond merely gaining a better understanding of classroom 
practice, the purpose of this comparative stance is to elaborate a new compre-

hensive network of concepts and methods through theoretical/empirical clarifications, supported by pragmatist philosophical considerations. (p. 316) In this quotation, the authors refer to the heuristic potential of comparative analyses in relation to classroom reality. We contend that this comparative work can be extended to teachers' documentation work. Indeed, comparing case of math and English teachers can demonstrate phenomena that could remain invisible, in the familiar context of a single subject. These phenomena, linked in our study with the interactions between teachers and resources, can be variously contextualized ranging from a very general, institutional level (e.g. when considering the use of the official curriculum) to a precise one related to a specific theme (e.g. when studying how a teacher chooses a resource for a precise teaching objective).

\section{Case studies on teachers' documentation work in English and mathematics}

\section{Documentation work in English: the case of Coralie}

\section{General presentation of Coralie's documents}

Using the methodology presented above, we followed Coralie's work in 2014-2015 with a grade 10 class while she was preparing and implementing a teaching unit entitled "Ordinary Heroes». Analyzing the data, we produced a «documentation table», for her teaching of this unit (table 1).

\section{Use of "authentic" and up-to-date resources}

The way Coralie chooses her resources is guided by several criteria such as their conformity with the official guidelines, their appropriateness for her students' levels and personal interests. But what plays a fundamental role when selecting new resources is that they refer to the most up-to-date information so as to stimulate her students' engagement. So, she renews her resources regularly. What she also explains in the interviews is that resources have to correspond to her own interests and tastes, and in particular must represent positive values. She emotionally invests her choice of resources. For instance, she explains, when she chose a video, that she had been 'seduced' by the resource.

\section{Use of video clips downloaded from YouTube}

Our methodological tools, here the reflective investigation combined with the documentation table, enable us to understand Coralie's use of videos and the factors shaping this use. Videos are resources that she uses regularly in accordance with the national curriculum. Indeed, video clips used to develop students' listening skills are among the main priorities for the teaching and learning of English as Foreign Language (EFL) in France. Consequently, 
Table 1. Documentation table for Coralie, teaching of a given theme (here: "Ordinary Heroes»)

\begin{tabular}{|c|c|c|c|}
\hline $\begin{array}{l}\text { Goal of the activity } \\
\text { Prepare and } \\
\text { implement... }\end{array}$ & Resources used & Rules of action & o.i. \\
\hline $\begin{array}{l}\text { A teaching unit } \\
\text { organized around a } \\
\text { cultural theme }\end{array}$ & $\begin{array}{l}\text { Textbooks } \\
\text { Internet (videos on } \\
\text { YouTube, texts, } \\
\text { images) Personal } \\
\text { files }\end{array}$ & $\begin{array}{l}\text { Checks first the class } \\
\text { textbook, then looks at } \\
\text { the documents she used } \\
\text { previously. } \\
\text { Types keywords in } \\
\text { an Internet browser } \\
\text { and follows what is } \\
\text { suggested. } \\
\text { Chooses resources } \\
\text { adapted to her students } \\
\text { and easy to use in class. }\end{array}$ & $\begin{array}{l}\text { "In order to stimulate my } \\
\text { students" engagement to } \\
\text { speak, I make them speak } \\
\text { thanks to documents that } \\
\text { interest them» } \\
\text { "The cultural theme must } \\
\text { have been endorsed and } \\
\text { recognized.» } \\
\text { "It has to fit in with the } \\
\text { agenda.» }\end{array}$ \\
\hline $\begin{array}{l}\text { A first lesson or/and } \\
\text { introduction to a } \\
\text { new theme }\end{array}$ & $\begin{array}{l}\text { Slide-shows made } \\
\text { up of images found } \\
\text { on the Internet. } \\
\text { The first pages of a } \\
\text { teaching unit in the } \\
\text { class textbook. }\end{array}$ & $\begin{array}{l}\text { Introduces each new } \\
\text { theme with a slide-show } \\
\text { including pictures } \\
\text { Uses pictures to make } \\
\text { her students speak }\end{array}$ & $\begin{array}{l}\text { «I always have a picture to } \\
\text { introduce new contents, } \\
\text { because the students focus } \\
\text { all together on this picture } \\
\text { The documents that I } \\
\text { give to my students have } \\
\text { pictures, otherwise they } \\
\text { do not memorize. And it } \\
\text { makes things meaningful } \\
\text { for them.» }\end{array}$ \\
\hline $\begin{array}{l}\text { A language } \\
\text { activity (reception, } \\
\text { production, inter- } \\
\text { action or mediation) }\end{array}$ & $\begin{array}{l}\text { Textbooks } \\
\text { The website } \\
\text { associated with the } \\
\text { class textbook } \\
\text { Internet (videos on } \\
\text { YouTube, texts and } \\
\text { images) } \\
\text { 'Home-made' } \\
\text { questionnaires } \\
\text { Students' reactions } \\
\text { to previous activities }\end{array}$ & $\begin{array}{l}\text { Listening: types } \\
\text { keywords in YouTube } \\
\text { Speaking: prepares } \\
\text { a questionnaire on a } \\
\text { video clip, especially to } \\
\text { introduce new vocab- } \\
\text { ulary. } \\
\text { Reading: chooses a text } \\
\text { with an image } \\
\text { Writing: proposes a text } \\
\text { model }\end{array}$ & $\begin{array}{l}\text { "We work on the new } \\
\text { vocabulary and then we're } \\
\text { following on a listening } \\
\text { activity.» } \\
\text { «I make them read a text to } \\
\text { help them to speak» } \\
\text { "A text model helps less } \\
\text { able students to under- } \\
\text { stand what is expected» } \\
\text { «I was seduced by the } \\
\text { positive values in the video } \\
{[\ldots] \text { they speak more easily }} \\
\text { when it's fun and positive. }\end{array}$ \\
\hline $\begin{array}{l}\text { A linguistic activity } \\
\text { (lexical, phono- } \\
\text { logical, syntactical } \\
\text { knowledge) }\end{array}$ & $\begin{array}{l}\text { Textbooks. } \\
\text { Videos on YouTube } \\
\text { Students' reactions } \\
\text { to previous activities }\end{array}$ & $\begin{array}{l}\text { Organises the black- } \\
\text { board into } 3 \text { parts }\end{array}$ & $\begin{array}{l}\text { "I always divide the board } \\
\text { into } 3 \text { parts so that the } \\
\text { students identify new } \\
\text { words, expressions and } \\
\text { short texts» }\end{array}$ \\
\hline An assessment & $\begin{array}{l}\text { Companion website } \\
\text { Class textbook }\end{array}$ & $\begin{array}{l}\text { Adapts the contents to } \\
\text { her students }\end{array}$ & $\begin{array}{l}\text { "My main reference is the } \\
\text { textbook» }\end{array}$ \\
\hline
\end{tabular}


many language teachers in our questionnaire (Boilevin et al., 2016, May) declare they very regularly use videos downloaded from Internet websites, usually YouTube. This is why we decided to focus on this particular resource.

We filmed Coralie at home and in class when preparing a teaching unit entitled «Ordinary Heroes». When doing her preparation, Coralie told us that she usually goes through several textbooks to see how the unit is structured, and what kind of texts, pictures and activities are included. Thus, following her usual approach, she first checked the school official textbook. There she first found a text about "Jessica Cox", a woman depicted as an ordinary hero. Indeed, she wanted to start her lesson with the study of a text as she strongly believes students need some written material in order to speak more easily afterwards.

She also considers that before working on a video clip, it is important to introduce new vocabulary, in relation to the introductory text. This is another o.i. In order to find a resource to implement the listening activity, she then decided to look for a video following an Internet link in the students' textbook. As the video clip she found on that site was quite old, she went on looking and finally found a revised trailer of this video on YouTube. During her preparation work, she explained that aesthetic criteria are essential in making her choice. In order to become a resource that will appeal to students, a video must look contemporary and attractive, and its contents must be topical. She also told us that she often chooses resources that carry positive values because she believes that it helps her students speak more. The triggering of speaking, with the help of a resource likely to raise her students' interest, is essential in her choice.

\section{Adaptation, modification of resources}

Once Coralie has selected authentic resources, she considers whether they need to be adapted and then concentrates on how to put them together. She rarely makes changes to original resources as she does not want to alter their authenticity, all the more so as she is not an English native speaker. She mainly associates pictures with new texts or audio and video files. In her teaching practice, images play a prominent role: according to her, they focus the students' attention, help them grasp the main meaning and thus memorize the content and, finally, assist their oral expression. Being able to design resources herself adapted to her students' needs strongly enhances her own motivation as a teacher. Moreover, we can observe that Coralie chooses and associates original resources according to her o.i.; but at the same time the resource itself (which has no teaching aim originally incorporated by its authors) influences Coralie's choices.

After having found the video clip, she spent an hour producing a transcript of the video to clarify its content. On the website associated with her class textbook, it was suggested that the video clip could be used without sound so as to focus the students' attention on the visual information. Coralie liked this idea because she believes pictures can focus students' attention on new material, and can help them get the main meanings. The textbook and its companion website 
are not institutional resources but can be considered as "officially approved" resources as they are widely used in French secondary upper schools and are recommended by educational authorities. So we argue that Coralie's faith in the suggested website derives from an o.i. that institutional, or widespread «officially approved» resources, are of high quality.

Documentation work in mathematics: the case of Valeria

\section{General presentation of Valeria's documents}

We followed Valeria with the same methodology in 2014-2015 when teaching about "variations of functions» in a grade 10 class. Analyzing the data, we produced a «documentation table» for her teaching of this theme (table 2).

\section{Course, exercises, assessments: a stable documentation work}

As regards the preparation of the course, and the choice of exercises for work in class or at home, Valeria does not search the Internet. In fact, her documentation work seems very steady over the years, and draws on traditional resources. Her course notes on functions were written many years ago - she does not remember when exactly - she reads these notes again and checks that they correspond to the official curriculum. For the exercises, the main resource she uses is the class textbook. She sometimes uses a pdf version of this textbook to project it in class but does not use an interactive e-textbook. For the assessments, she uses other paper textbooks (not the class textbook); the main o.i. guiding her choice for the assessment seems to be that the exercises chosen must be very similar to those solved in class.

\section{Use of digital resources}

Valeria mainly uses two kinds of digital resources: a platform called LaboMEP and an institutional repository called Eduscol.

LaboMEP is designed by an association of mathematics teachers, Sésamath (Sabra \& Trouche, 2011). It is a complete virtual learning environment, consisting of textbooks, software and online exercises. Valeria only uses the online exercises. She uses it to reinforce her students' previous knowledge and be sure that all the students master the necessary knowledge before she starts introducing new content. It is connected with an o.i. she developed over the years: any grade 10 class is very heterogeneous. In this upper secondary school, the students come from more than twenty different lower secondary schools (indeed it offers specific technical options). She does not know what they have learned before; grade 9 teachers might have quite different approaches. LaboMEP enables her to choose different exercises for different students. The students work on it in class, but at their own pace thanks to the software feedback and the help it proposes. Valeria considers that she could not provide such individualized feedback herself because of lack of time. 
Table 2. 'Documentation table' for Valeria, teaching of a given theme (here: "variation of functions", grade 10).

\begin{tabular}{|c|c|c|c|}
\hline $\begin{array}{l}\text { Goal of the } \\
\text { activity: Prepare } \\
\text { and implement... }\end{array}$ & Resources used & Rules of action & O.I. \\
\hline $\begin{array}{l}\text { Stabilization } \\
\text { of previous } \\
\text { knowledge }\end{array}$ & $\begin{array}{l}\text { «LaboMEP» (online } \\
\text { exercises) }\end{array}$ & $\begin{array}{l}\text { Valeria chooses exercises } \\
\text { in LaboMEP to test } \\
\text { whether the students } \\
\text { master previous } \\
\text { knowledge and to } \\
\text { supplement if necessary. }\end{array}$ & $\begin{array}{l}\text { "I use LaboMep for } \\
\text { training on grade } 9 \\
\text { knowledge» }\end{array}$ \\
\hline $\begin{array}{l}\text { An introductory } \\
\text { problem }\end{array}$ & $\begin{array}{l}\text { Internet Browser } \\
\text { National repository } \\
\text { 'Eduscol' } \\
\text { Institutional websites } \\
\text { Textbooks (6-7 } \\
\text { different) } \\
\text { Sometimes: e-mail } \\
\text { exchanges with } \\
\text { colleagues; software (e.g. } \\
\text { Geogebra) and video } \\
\text { projector } \\
\text { Students' productions, } \\
\text { students' reactions in } \\
\text { class }\end{array}$ & $\begin{array}{l}\text { In the institutional } \\
\text { repository browser, } \\
\text { Valeria types the level: } \\
\text { grade 10, and the precise } \\
\text { aim of the lesson: for } \\
\text { example, "variation of } \\
\text { functions» } \\
\text { A problem is chosen and } \\
\text { then modified, leading } \\
\text { to a sheet given to each } \\
\text { student in class. } \\
\text { The students work on } \\
\text { the sheet; when software } \\
\text { is used (GeoGebra), it is } \\
\text { projected in class. }\end{array}$ & $\begin{array}{l}\text { «I look at websites from } \\
\text { secondary schools or } \\
\text { institutional ones» } \\
\text { «I firstly search on the } \\
\text { Eduscol website» } \\
\text { «I change each year my } \\
\text { introductory problems» }\end{array}$ \\
\hline Course (synthesis) & $\begin{array}{l}\text { Official curriculum (file } \\
\text { downloaded from the } \\
\text { Internet) } \\
\text { Files from the previous } \\
\text { year, Textbooks, } \\
\text { Students' sheets. }\end{array}$ & $\begin{array}{l}\text { Valeria checks her course } \\
\text { from the previous year, } \\
\text { and does not modify it. }\end{array}$ & $\begin{array}{l}\text { "I don't spend a lot of } \\
\text { time on the content of } \\
\text { the course, ..., textbooks } \\
\text { exist, this is what I did } \\
\text { last years, [the course] } \\
\text { doesn't change very } \\
\text { often" }\end{array}$ \\
\hline $\begin{array}{l}\text { Exercises (in class } \\
\text { and at home) }\end{array}$ & $\begin{array}{l}\text { The class textbook } \\
\text { Files from the previous } \\
\text { year }\end{array}$ & $\begin{array}{l}\text { Valeria chooses most of } \\
\text { the exercises in the class } \\
\text { textbook. }\end{array}$ & $\begin{array}{l}\text { "I pay attention to the } \\
\text { choice of homework, I } \\
\text { want [students] to use } \\
\text { their textbooks.» } \\
\text { "Exercises for homework } \\
\text { are always, always taken } \\
\text { from their textbooks» }\end{array}$ \\
\hline Assessment & $\begin{array}{l}\text { Textbooks (not the class } \\
\text { textbook) } \\
\text { Files from previous years } \\
\text { Observation of the } \\
\text { students in class }\end{array}$ & $\begin{array}{l}\text { Valeria chooses several } \\
\text { exercises, covering the } \\
\text { various aspects of the } \\
\text { chapter. }\end{array}$ & $\begin{array}{l}\text { "Assessment is based } \\
\text { on the activities we do } \\
\text { together in class» } \\
\text { «I synthesize everything } \\
\text { we spoke about, every } \\
\text { point I highlighted in } \\
\text { class and I say to myself } \\
\text { that as I focused on it } \\
\text { a lot, I will therefore } \\
\text { ask about it in the } \\
\text { assessment» }\end{array}$ \\
\hline
\end{tabular}


Valeria also uses Eduscol, an institutional repository, to search for introductory activities. She usually starts each new chapter by giving her students an introductory problem. She does not keep records of the introductory problems she uses from year to year (unlike the course). She likes to search the Internet for new introductory problems each year. We observed her choice on Eduscol of a particular resource, for the introduction of the concept of variation of functions. This choice was guided by very precise teaching objectives: here, the introduction of variations of functions; she also believes that a dynamic geometric figure helps to understand the concept of variations. In fact, the resource she selected on Eduscol includes a GeoGebra file. While the LaboMEP exercises are used as they are, without any modifications, for introductory activities Valeria modifies the resources she finds on Eduscol.

\section{Adaptation, modification of resources}

As regards the introductory activity mentioned above, for the variations of functions, Valeria modified the resource she found on Eduscol, deleting parts of it because of time limitations, and changing the order of the questions, because she wants to emphasize the intuitive aspects of variations (using the dynamic figure). The activity consists of a graph, to be completed by the students. She modifies it, using a kind of graphic familiar to her students. Finally, she types out her own students' worksheet, including these modifications. We observed the corresponding lesson. It actually took more time than initially planned by Valeria (2 hours instead of $1 \mathrm{~h} 30$ ), because the students spent a lot of time on the beginning of the activity. In fact, it was more difficult than expected and led her to say (in the post-lesson interview) that she should have given the beginning as homework to avoid this waste of time. But the students were actively involved in the mathematical activity, and they were, as planned, interested by the use of Geogebra. Valeria considers that the dynamic geometric figure played its expected role. We note that the design process is a continuous process: the resource found online already incorporates remarks on its use in class, it has been designed and tested by colleagues. Nevertheless, Valeria's experience with the students is very important, and would lead her to a new stage of design for further use of the resource.

\section{The two cases and their comparison: discussion and results}

The two questions guiding our work were: (1) What are the documents developed by teachers, in particular, how do teachers' o.i. interact with their documentation work? (2) What is the impact of digital resources and of their availability on teachers' documentation work? In this section we present elements of answers to these two questions drawn from the two cases presented above and from their comparison. 
Operational invariants are developed by individuals; nevertheless, their development is influenced by the socio-historical context where these individuals' activity takes place. For our study, this means in particular that some of the o.i. developed by the two teachers are linked with specific features of the teaching of their discipline at upper secondary school (these features can be considered as outcomes of a didactic transposition process).

In mathematics, we firstly observe that Valeria starts her grade 10 chapter by reviewing corresponding grade 9 contents. The mathematics curriculum is indeed organized along the school years according to 'learning trajectories' (Confrey, Maloney \& Corley, 2014); Valeria, like all mathematics teachers, has developed o.i. linked with these trajectories (e.g. «students must know the notion of graph of function before learning variations») and this guides her documentation work. The stability of her course and exercises on functions can also be considered as linked with o.i. shared with most mathematics teachers. Indeed, in spite of important evolution in the official curriculum during the last 50 years, the content around functions has remained steady over this period. One of the consequences seems to be that mathematics teachers have developed o.i. like «the teaching of functions must start with simple examples like linear functions» etc., because of the stability of the didactical transposition. We also infer that Valeria has developed an o.i. like: «Each new chapter should start with an introductory activity». Indeed, starting a chapter with such an activity is a practice shared by most mathematics teachers, and linked with other shared o.i. like «the need to connect mathematics with real-life situations» (Rousset-Bert, 2001).

In English, the starting point of Coralie's chapter is the observation and oral description of the picture of a hero. Stimulating her students' engagement, notably to speak, is, as we said, essential in her documentation work. The importance of making students act by themselves in and with the language that is studied is linked with the action-based approach (Council of Europe, 2001) that is particularly rooted in Austin's postulate, "how to do things with words" (1962), and that has been widely implemented in France over the last 30 years in foreign language teaching (Puren, 2008). Teachers have developed o.i. like «learners have to speak as much as possible». The importance of showing techniques is another specific feature of the teaching of English (Gruson, 2007), linked with o.i. shared with most English teachers, and that Coralie summarizes as follows: «a model helps them to understand».

Nevertheless, all mathematics or English teachers do not design the same teaching. From our documentational approach perspective, we interpret this as a consequence of the influence of individual o.i., developed along interactions with various resources. We observed in particular in our study that students' productions constitute important resources for both teachers; interactions with different students can thus lead to the development of such individual o.i.

Coralie and Valeria spend a lot of time designing their own resources or modifying existing resources. The only resources used by Valeria without 
modification are the online exercises in LaboMEP and the textbook exercises. She modifies all the other resources she chooses on websites or in books: adding a graph in an introductory problem, for example. Coralie creates a complete teaching resource integrating, for example, a video found on the Internet. Coralie designs a teaching medium from authentic material, while Valeria modifies a resource already designed for teaching purposes. But they both need to change the existing resources; in terms of documentational approach, we claim that teachers need to develop documents, incorporating their personal o.i.

Concerning the impact of digital resources, we observe differences between the two cases, in particular resulting from the specific features of each discipline, but also common elements.

In mathematics, Valeria uses the online exercises in LaboMEP to review grade 9 contents. This is linked with an o.i. concerning the need to reactivate previous knowledge; the digital resource opens up the possibility to organize this as homework, with a feedback on their work for students (by the software), and an access to this work for the teacher. Using LaboMEP also leads Valeria to organize a more differentiated teaching, according to her students' different needs, and to develop o.i. linked with her interest in differentiated teaching. Moreover, Valeria uses many specific mathematical software - we saw above the example of GeoGebra - this use is linked with the official curriculum and initial mathematics teacher education evolution, which now, in France, dedicate an important place to such software. Another noticeable evolution in recent years is the development of communities of teachers designing online resources (Sabra $\&$ Trouche, 2011). Alike many other mathematics teachers, Valeria uses such resources.

In English, Coralie does not use any software designed for supporting the learning of English; this is linked with the fact that software for the learning of foreign languages is not much developed and, as a consequence, is not really mentioned in the official curriculum. We can add that Coralie does not share with other teachers the resources she designs, and she does not use resources developed by English teacher communities either. This is consonant with other studies (for instance, Whyte, 2016) showing that language teachers are not comfortable sharing resources in wide networks. Despite the possibilities made available by digital resources, her documentation work remains individual, in particular because she changes her resources every year. This is linked with an o.i. concerning the importance of using as many up-to-date resources as possible in order to stimulate students' interest and engagement to speak.

Concerning common impact of digital resources, we first notice that both teachers use a large number of digital resources: videos for English; online exercises, free software and introductory problems, for mathematics. Coralie and Valeria also both spend a lot of time seeking out new resources. We claim that this search for 'new resources' each year (for Valeria, concerning mostly introductory activities) is fostered by the profuse availability of digital resources. Both 
teachers still use textbooks on paper, yet they also search the Internet and know that, this way, they can renew their teaching material. Some similar o.i. guide this search. Firstly, they both trust and use consistently 'officially approved' resources. The need to be in line with the official curriculum is an o.i. shared by both teachers. Secondly, they also both choose resources encouraging visualization: a dynamic figure in mathematics, because Valeria considers that it can help students understand variation; various pictures in English, because Coralie thinks that they help students understand and learn new contents. In both cases these visual resources are chosen because they provide a representation of the concepts or vocabulary considered likely to foster learning; the usefulness of such a representation is an o.i. resulting from previous use of similar resources.

We only studied the case of two teachers, and do not pretend to provide general answers to our questions. Nevertheless, it enables us to draw some conclusions and to present further perspectives.

\section{Conclusion and perspectives}

The documentational approach has been developed to study teachers' documentation work and its consequences on teacher professional development. The two cases studied above confirm the importance of this documentation work within teachers' professional activity. They also evidence how teachers interact with resources: e.g. the use of LaboMEP by Valeria is linked with an o.i. concerning the need to review previous knowledge; but it also leads her to develop new o.i. and practices concerning differentiated teaching. Similar statements have already been made in research works concerning secondary school teachers, in mathematics in particular. The specific contribution of this study comes from the comparison of two very different disciplines.

This comparison provides new insights on teachers' documentation work and on the consequences of the use of digital resources. It leads us to sort out different kinds of o.i.: general o.i. that can be shared by secondary school teachers for all disciplines («it is interesting to renew teaching resources each year»); o.i. specific to the discipline; and more individual o.i., which can be consequences of teachers' personal documentation trajectories (Rocha, 2018). We claim in particular that studying the interactions between teachers' and resources, for a given school discipline, can contribute to better understand this discipline's identity and specific features.

The comparison also leads us to sort out different consequences of the availability of digital resources: e.g. the use of videos as 'authentic' resources in English and the use of specific mathematical software in mathematics. We also observed the use of digital resources designed by communities in mathematics, and a more individual documentation work in English. These observations suggest recommendations for practice: how could English teachers use specific software? How 
could mathematics teachers use videos? How is it possible to foster collective design and sharing resources by English teachers?

In the near future, we can assume that the use of digital resources will continue to increase. In Pepin, Gueudet and Trouche (2017), we analyzed the consequences of digital curriculum in terms of development of teachers' design capacity, for mathematics teachers. Further comparative studies could enlighten the specific or general features of this design capacity. More research on the documentation work of teachers from different subjects is needed, investigating more cases and, in particular, more international comparisons in order to examine possible national features, and also to develop our methodological approach further.

\section{References}

Adler, J. (2000). Conceptualising resources as a theme for teacher education. Journal of Mathematics Teacher Education, 3, 205-224.

Austin, J. (1962). How to do things with words. Cambridge, MA: Harvard University Press.

Baxandall, M. (1985). Patterns of intention: on the historical explanation of pictures. New Haven, CT: Yale University Press.

Boilevin, J.-M., Gérard, V., Gueudet, G., Guillemot, V., Gruson, B., Jameau, A., Lebaud, M.-P., Le Hénaff, C, Ménard, J. \& Thépenier, L. (2016, mai). Les ressources des professeurs et leurs évolutions. Une étude au lycée Joliot Curie. Poster présenté à la Gème Rencontre Nationale des LéA. Lyon, France.

Chevallard, Y. \& Joshua, M.-A. (1991). La Transposition didactique, du savoir savant au savoir enseigné. Grenoble: La Pensée Sauvage.

Collins, M. (2011). Language and Practice. Social Studies of Science, 41, (2), 271-300.

Confrey, J., Maloney, A. P. \& Corley, A. K. (2014). Learning trajectories: A framework for connecting standards with curriculum. ZDM, 47, 719-733.

Council of Europe. (2001). Common European framework of reference for languages: learning, teaching, assessment. Cambridge: Cambridge University Press.

Gruson, B. (2007). Agir, interagir et rétroagir en anglais : Analyse de la pratique d'un professeur de CM2 et de ses élèves lors d'une situation de "pairwork». Carrefours De l'Éducation, 23, 39-54.

Gueudet, G., Pepin, B. \& Trouche, L. (Éd.) (2012). From Textbooks to 'Lived' Resources: Mathematics Curriculum Materials and Teacher Documentation. New York, NY: Springer.

Guin, D., Ruthven K. \& Trouche, L. (Éd.). (2005). The didactical challenge of symbolic calculators: turning a computational device into a mathematical instrument. New York, NY: Springer.

Ligozat, F., Amade-Escot, C. \& Östman, L. (2015). Beyond subject specific approaches of teaching and learning: Comparative didactics. Interchange, 46, (4), 313-321.

Mercier, A., Schubauer-Leoni, M. L. \& Sensevy, G. (2002). Vers une didactique comparée. Revue française de pédagogie, 141, (1), 5-16.

Passeron, J.-C., \& Revel, J. (2005). Penser par cas. Paris: Éditions de l'EHESS.

Pédauque, R. T. (coll.) (2006). Le document à la lumière du numérique. Caen: C \& F éditions.

Pepin, B., Gueudet, G. \& Trouche, L. (2017). Refining teacher design capacity: Mathematics teachers' interactions with digital curriculum resources, ZDM, 49, (5), 799-812.

Puren, C. (2008). Explication de textes et perspective actionnelle: la littérature entre le dire scolaire et le faire social, Le Langage et L'Homme, Revue de didactique du français, 43, (1), 143-166. 
Rabardel, P. (1995). Les hommes et les technologies: Approche cognitive des instruments contemporains. Paris: Armand Colin.

Rocha, K. M. (2018). Uses of Online Resources and Documentational Trajectories: the Case of Sésamath. In L. Fan, L. Trouche, S. Rezat, C. Qi \& J. Visnovska (Éd.), Research on Mathematics Textbooks and Teachers' Resources: Advances and issues (pp. 235-258). New York, NY: Springer.

Rousset-Bert, S. (2001). Les activités: un thème à retravailler. Petit x, 56, 61-79.

Sabra, H. \& Trouche, L. (2011). Collective design of an online math textbook: when individual and collective documentation works meet. In M. Pytlak, T. Rowland, \& E. Swoboda (Éd.), Proceedings of CERME 7 (pp. 2356-2366). Rzeszów, Poland.

Sensevy, G. (2011). Le sens du savoir. Éléments pour une théorie de l'action conjointe en didactique. Bruxelles: De Boeck.

Sensevy, G., Gruson, B. \& Forest, D. (2015). On the nature of the semiotic structure of the didactic action: The Joint Action Theory in Didactics within a Comparative Approach. Interchange, 46, (4), 387-412.

Vergnaud, G. (1998). Toward a cognitive theory of practice. In A. Sierpinska \& J. Kilpatrick (Éd.), Mathematics education as a research domain: A search for identity (pp. 227-241). Dordrecht: Kluwer Academic Publisher.

Vygotsky, L. (1978). Mind in society. Cambridge, MA: Harvard University Press.

Whyte, S. (2016). From solitary thinkers to social actors: OER in multilingual CALL teacher education. ALSIC, 19, (1). Retrieved from http://alsic.revues.org/2906.

Keywords: Comparative didactics, digital resources, documentational approach, teachers' resources, upper secondary school

\section{Die Arbeit der Lehrperson mit digitalen Bildungsressourcen: Ein Vergleich zwischen dem Lehren von Mathematik und Englisch}

\section{Zusammenfassung}

Die aktuelle Verbreitung von Ressourcen über das Internet führt zu tiefgreifenden Veränderungen in der Aktivität von Lehrpersonen. Wir untersuchen diese Veränderungen im Rahmen des dokumentarischen Ansatzes. Wir vergleichen zwei Fallstudien: eine Englischlehrerin und eine Mathematiklehrerin. Beide arbeiten in einem Gymnasium in Frankreich. Wir fanden in beiden Fällen die substantielle Verwendung von digitalen Ressourcen, jedoch auf je eigene Art und Weise. Diese Unterschiede werden dargelegt und diskutiert. Die beiden Fälle werden genutzt, um allgemeinere Folgerungen bezüglich Gestaltung, Nutzung und Teilen von digitalen Ressourcen darzulegen.

Schlagworte: Digitale Ressourcen, dokumentarischer Ansatz, Gymnasium, Lehrpersonen, Ressourcen, Vergleichende Didaktik 


\section{Le travail des professeurs avec des ressources numériques. Une comparaison entre l'enseignement des mathématiques et celui de l'anglais}

\section{Résumé}

La prolifération de ressources disponibles en ligne amène de profondes modifications du travail des professeurs. Nous étudions ces modifications en nous référant au cadre théorique et à la méthodologie de l'approche documentaire du didactique. Nous comparons deux études de cas: un professeur d'anglais, et un professeur de mathématiques, travaillant tous les deux dans le même lycée en France. Dans les deux cas nous observons un usage important de ressources numériques, mais de nature différente. Nous présentons et discutons ces différences, qui mettent au jour des caractéristiques du travail documentaire des professeurs. Nous nous appuyons sur ces cas pour formuler des observations plus générales à propos de la conception, des usages et du partage de ressources en ligne.

Mots clés: Didactique comparée, ressources numériques, approche documentaire, ressources des professeurs, lycée

\section{Indagine sul lavoro dei docenti alle prese con le risorse digitali. Un confronto tra l'insegnamento della matematica e dell'inglese}

\section{Riassunto}

La proliferazione delle risorse disponibili in rete arreca delle profonde modifiche al lavoro dei docenti. Riferendosi al quadro teorico e alla metodologia dell'approccio documentario in ambito didattico, il presente articolo restituisce un'analisi delle modifiche che intervengono nelle pratiche d'insegnamento. In particolare, sono paragonati due casi di studio: un docente d'inglese e un docente di matematica, che lavorano tutti e due nello stesso liceo in Francia. In ambedue i casi, si osserva un uso importante di risorse informatiche ma di natura diversa. Tali differenze, che fanno sorgere delle caratteristiche del lavoro documentario dei docenti, vengono presentate e discusse. Sulla base di tali analisi, sono poi formulate delle osservazioni più generali a proposito della concezione e degli usi di queste risorse e anche di come vengono condivise in rete.

Parole chiave: Risorse dei professori, approccio di documento, risorse informatiche, didattica comparata, liceo 
